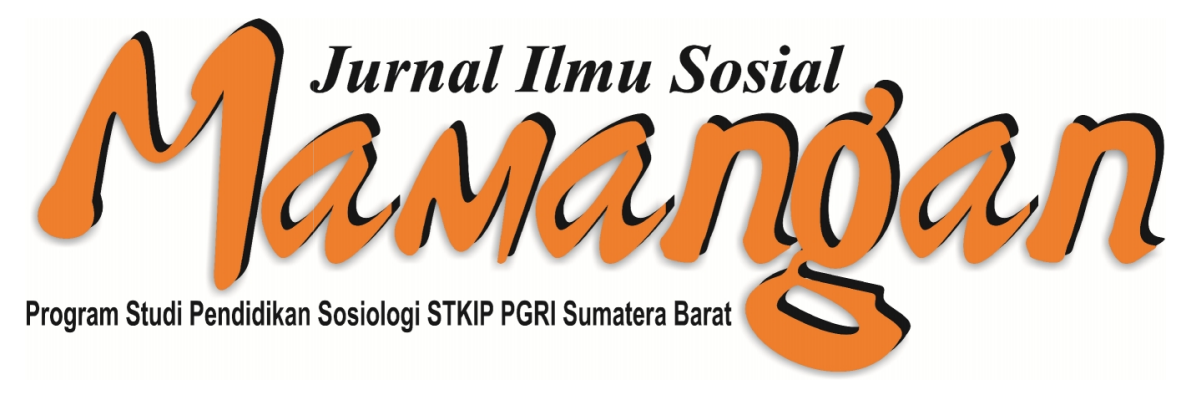

Jurnal Ilmu Sosial Mamangan

Volume 5, Nomor 2, Juli-Desember 2016

Resolusi Konflik Tapal Batas Kabupaten Rokan Hulu Dan Kabupaten Kampar, Propinsi Riau

Penulis : Suryaningsih \& Silsila Asri

Sumber : Jurnal Ilmu Sosial Mamangan, Volume 5, Nomor 2, Juli-Desember 2016

Diterbitkan Oleh : Laboratorium Pendidikan Sosiologi, STKIP PGRI Sumatera Barat

Untuk Mengutip Artikel ini :

Suryaningsih \& Silsila Asri, 2016. Resolusi Konflik Tapal Batas Kabupaten Rokan Hulu Dan Kabupaten Kampar, Propinsi Riau. Jurnal Ilmu Sosial Mamangan, Volume 5, Nomor 2, Juli Desember 2016: 60-68.

Copyright (C) 2016, Jurnal Ilmu Sosial Mamangan ISSN : 2301-8496 (Print), ISSN : 2503-1570 (Online)

Laboratorium Pendidikan Sosiologi STKIP PGRI Sumatera Barat 


\title{
Resolusi Konflik Tapal Batas Kabupaten Rokan Hulu Dan Kabupaten Kampar, Propinsi Riau
}

\author{
Suryaningsih $^{1} \&$ Silsila Asri ${ }^{2}$ \\ 1\&2 Program Studi Ilmu Pemerintahan, STISIP Imam Bonjol \\ ${ }^{1}$ Email : aseh2309@gmail.com \\ 2Email : la tansa2003@yahoo.com
}

\begin{abstract}
Conflict between Rokan Hulu District and Kampar District in Riau Province is conflict about the seizing territory of five villages on the border in both districts. Litigation process which was persued by the central government inresolving the conflict in the border of both districts did not solve that problem. Both districts do not accept the decision that has been arranged by the central government. It was proved by the allocation of village budget for the five villages from the both districts. This also lead to social tension and conflict in the community of five villages which then make the conflict more widespread. This study used a qualitative method and aim to describe the conflict resolution in the determining the boundary between District of Rokan Hulu and District of Kampar.
\end{abstract}

Keywords: Conflict, Litigation, Conflict Resolution, Boundary.

\begin{abstract}
ABSTRAK
Konflik antara Kabupaten Rokan Hulu dengan Kabupaten Kampar di Provinsi Riau merupakan perebutan lima desa yang ada diperbatasan kedua Kabupaten. Jalur Litigasi/peradilan yang ditempuh oleh pemerintah pusat dalam menyelesaikan konflik di tapal batas kedua kabupaten tidak menyelesaikan persoalan. Kedua kabupaten tidak menerima keputusan yang telah ditetapkan oleh pemerintah pusat dengan masih diberikannya Alokasi Dana Desa di lima desa oleh masing-masing kabupaten. Hal ini kemudian memicu ketegangan dan konflik sosial di masyarakat lima desa yang membuat konflik semakin meluas. Penelitian ini menggunakan metode kualitatif dan bertujuan untuk memaparkan resolusi konflik dalam penentuan tapal batas di Kabupaten Rokan Hulu dan Kabupaten Kampar.
\end{abstract}

Kata Kunci: Konflik, Litigasi, Resolusi Konflik, Tapal Batas.

\section{PENDAHULUAN}

Undang-Undang No. 22 Tahun 1999 tentang Pemerintahan Daerah memberikan ruang kepada daerah untuk melakukan pemekaran. Undang-undang ini kemudian melahirkan Peraturan Pemerintah No. 129 Tahun 2000 tentang Persyaratan pembentukan dan kriteria pemekaran, penghapusan, dan penggabungan daerah (telah direvisi menjadi PP No. 78 Tahun 2007 Tentang Pemekaran Wilayah). Dengan 
adanya peluang dan kesempatan yang diberikan tersebut maka pemekaran daerah menjadi semakin marak dan tidak terkendali. Berdasarkan data dari Kementrian Dalam Negeri terlihat bahwa sejak tahun 1999 hingga tahun 2014 jumlah Daerah Otonom Baru (DOB) di Indonesia ada 8 provinsi, 182 kabupaten, dan 33 kota (Kemendagri, 2015). Terlihat bahwa dalam rentang waktu 15 tahun telah terbentuk 223 daerah baru di Indonesia.

Jika dilihat dari tujuan formal pemekaran daerah berdasarkan PP No. 129 Tahun 2000 tersebut adalah untuk meningkatkan kesejahteraan masyarakat melalui peningkatan pelayanan kepada masyarakat, percepatan pertumbuhan kehidupan demokrasi, percepatan pelaksanaan pembangunan perekonomian daerah, percepatan pengelolaan potensi daerah, peningkatan keamanan dan ketertiban, dan peningkatan hubungan yang serasi antara pusat dan daerah. Akan tetapi, tujuan dari pemekaran daerah yang telah dilakukan sejak tahun 1999 tersebut belum menciptakan good governance (Roth, 2007). Hal ini dikarenakan motif untuk melakukan pemekaran daerah lebih bersifat politis.

Menurut Bank Dunia ada empat faktor yang memicu maraknya pemekaran daerah di Indonesia, pertama adanya motif untuk efektivitas dan efesiensi administrasi pemerintahan karena luasnya daerah, penduduk yang menyebar dan ketertinggalan pembangunan. Kedua, kecendrungan untuk homogenitas (bahasa, agama, etnis, dan lainlain). Ketiga, adanya kemanjaan fiskal yang dijamin oleh undang-undang, dan Keempat, motif pemburu rente para elit (Ratnawati, 2009). Berdasarkan hasil dari penelitian yang telah dilakukan oleh para ahli dapat disimpulkan bahwa faktor yang paling dominan untuk melakukan pemekaran daerah di Indonesia adalah adanya motif pemburu rente para elit (Roth, 2007); (Tirtosudarmo, 2008); (Pamungkas, 2008); dan (Tahara, 2008).

Pemekaran daerah pada dasarnya memiliki wajah ganda, yakni selain memiliki dampak positif juga memiliki dampak negatif (Ratnawati, 2010). Dampak positif yang dirasakan dari pemekaran tersebut adalah telah terjadi peningkatan Pendapatan Asli Daerah (PAD) meskipun masih tinggi ketergantungan pada Dana Alokasi Umum
(DAU) dan terjadinya peningkatan pada proporsi belanja pembangunan meskipun proporsi terhadap belanja rutin masih kecil (BAPPENAS, 2008). Selain itu, berdasarkan hasil studi dari Lembaga Administrasi Negara (2005) menunjukkan bahwa untuk aspek kesejahteraan masyarakat, khususnya dari indikator ekonomi dan sosial secara umum mengalami peningkatan. Pemekaran daerah kemudian tidak bisa dilepaskan dari dampak negatif yang mengiringinya karena telah menimbulkan masalah sejak awal pemekaran. Pada awal pembentukan daerah baru sering diwarnai dengan konflik perbatasan, konflik ibukota, masalah utangpiutang, dan perebutan aset-aset daerah(Ratnawati, 2010).

Pemekaran kabupaten/kota di Provinsi Riau juga membawa dampak negatif, salah satunya adalah perebutan wilayah/tapal batas antara kabupaten induk dengan kabupaten hasil pemekaran serta dengan Provinsi Sumatera Utara. Permasalahan tapal batas tersebut terjadi antara Kabupaten Indragiri Hulu dengan Kabupaten Indragiri Hilir, Kabupaten Rokan Hulu dengan Padang Lawas (Sumatera Utara), dan antara Kabupaten Rohul dengan Kabupaten Kampar. Provinsi Riau ini merupakan salah satu daerah yang juga ikut serta dalam pemekaran daerah pada tahun 1999. Daerah ini pada awalnya memiliki 6 (enam) kabupaten/kota, namun setelah dilakukannya pemekaran bertambah menjadi 12 (dua belas) kabupaten/kota. Pemekaran di Provinsi Riau terdapat dalam Undang-undang No. 53 Tahun 1999 tentang Pembentukan Kabupaten Pelalawan, Kabupaten Rokan Hulu, Kabupaten Rokan Hilir, Kabupaten Siak, Kabupaten Karimun, Kabupaten Natuna, Kabupaten Kuantan Singingi, dan Kota Batam. Enam kabupaten hasil pemekaran tersebut adalah; pertama, 3 (tiga) kabupaten hasil dari pemekaran Kabupaten Bengkalis, yakni Kota Dumai, Kabupaten Rokan Hilir, dan Kabupaten Siak. Kedua, 1 (satu) kabupaten yang merupakan hasil pemekaran dari Kabupaten Indragiri Hulu, yakni Kabupaten Kuantan Singingi. Ketiga, 2 (dua) Kabupaten yang merupakan hasil pemekaran dari Kabupaten Kampar, yakni Kabupaten Pelalawan dan Kabupaten Rokan Hulu.

Konflik tapal batas antara Kabupaten Rokan Hulu dengan Kabupaten Kampar ini mulai muncul pada tahun 2005. Kedua 
kabupaten ini memperebutkan lima desa yang berada diperbatasan kedua kabupaten. Lima desa tersebut adalah Desa Rimbo Jaya, Desa Tanah Datar, Desa Rimba Makmur, Desa Muara Intan, dan Desa Intan Jaya. Kabupaten Kampar yang merupakan kabupaten induk tetap mempertahankan lima desa dengan memasukkannya kedalam Kecamatan Tapung Hulu. Sedangkan Kabupaten Rokan Hulu memasukkan lima desa itu kedalam dua kecamatan, yakni Kecamatan Kunto Darussalam (Desa Tanah Datar, Desa Intan Jaya, dan Desa Muara Intan) dan Kecamatan Pagaran Tapah Darussalam (Desa Rimbo Jaya dan Desa Rimba Makmur).

Hingga saat penelitian ini dilakukan, konflik tapal batas antara kedua kabupaten belum terselesaikan. Berbagai upaya hukum telah ditempuh oleh pemerintah Provinsi Riau dan pemerintah pusat melalui Kementrian Dalam Negeri, akan tetapi konflik masih terus ber-eskalasi. Konflik muncul ke permukaan pada tahun 2008 yakni terjadi bentrokan di masyarakat terkait dengan keberadaan mereka dalam pemilihan Gubernur Riau tahun 2008. Penyelesaian yang ditempuh saat itu tidak menyelesaikan akar permasalahan, hal ini terlihat dari munculnya kembali konflik pada tahun 2014. Konflik dapat dihindari dan diselesaikan dengan adanya common will dari pembuat kebijakan. Konflik tapal batas dalam Tulisan ini akan membahas dan menganalisa resolusi konflik tapal batas antara Kabupaten Kampar dengan Kabupaten Rokan Hulu. Pemahaman tentang akar dan dinamika konflik sangat penting sebelum mengkaji tentang resolusi konfliknya. Oleh sebab itu, tulisan ini juga akan mengkaji pertama, akar penyebab konflik antara Kabupaten Rokan Hulu dengan Kabupaten Kampar dan kedua, terkait dengan dinamika konfliknya dari tahun 2005 hingga saat ini.

\section{METODE}

Penelitian ini menggunakan pendekatan kualitatif deskriptif karena lebih mampu untuk mendeskripsikan dan menganalisa resolusi konflik tapal batas antara Kabupaten Rokan Hulu dengan Kabupaten Kampar Provinsi Riau. Data dalam penelitian ini didapatkan melalui data primer dan data sekunder. Data primer didapatkan melalui wawancara dan informan penelitian dipilih dengan menggunakan teknik snowball sampling. Untuk data sekunder peneliti telah dapatkan melalui dokumentasi (surat-surat, kesimpulan-kesimpulan pertemuan, dokumen-dokumen administratif, dan beritaberita terkait konflik antara kabupaten Rokan Hulu dan Kampar, baik melalui media cetak maupun dari internet). Teknik pengumpulan data yang digunakan adalah dengan triangulasi, yakni menggunakan wawancara dan dokumentasi untuk sumber data yang sama secara serempak dan untuk mendapatkan data dari sumber yang berbeda-beda dengan teknik yang sama.

\section{AKAR DAN DINAMIKA KONFLIK: PEMETAAN PENYELESAIAN KONFLIK TAPAL BATAS KABUPATEN ROKAN HULU DAN KABUPATEN KAMPAR}

Dalam upaya memahami resolusi konflik tapal batas antara Kabupaten Kampar dengan Kabupaten Rokan Hulu, maka perlu ditelusuri dan diidentifikasi faktor penyebab/akar konflik dan dinamika konfliknya. Pemahaman tersebut dapat ditelusuri dari sejarah pemekaran Kabupaten Kampar. Pada tahun 1999 Kabupaten Kampar dimekarkan menjadi 3 kabupaten, yakni Kabupaten Pelalawan, Kabupaten Rokan Hulu, dan Kabupaten Kampar. Pemekaran tersebut termaktub dalam Undang-undang No. 53 Tahun 1999 Tentang Pembentukan Kabupaten Pelalawan, Kabupaten Rokan Hulu, Kabupaten Rokan Hilir, Kabupaten Siak, Kabupaten Karimun, Kabupaten Natuna, Kabupaten Kuantan Singingi, dan Kota Batam yang telah direvisi menjadi

Adapun alasan dilakukannya pemekaran Kabupaten Kampar adalah karena luasnya wilayah kabupaten ini. Kabupaten Kampar sebelum dimekarkan memiliki luas wilayah $30.563,72 \mathrm{~km}^{2}$. Dalam rangka membantu tugas penyelenggaraan pemerintahan, pelaksanaan pembangunan, dan pembinaan kemasyarakatan pada masa itu, maka dibentuklah wilayah kerja pembantu bupati. Untuk kawasan Timur dibentuk wilayah kerja Pembantu Bupati Kampar Wilayah II yang meliputi empat kecamatan, yakni; Kecamatan Bunut, Kecamatan Langgam, Kecamatan Kuala Kampar, dan Kecamatan Pangkalan Kuras. Luas seluruh wilayah kerja Pembantu Bupati Kampar Wilayah II ini adalah $12.490,42 \mathrm{~km}^{2}$. 
Kawasan sebelah Barat Kabupaten Kampar dibentuk wilayah kerja Pembantu Bupati Kampar Wilayah I yang meliputi tujuh kecamatan, yakni; Kecamatan Tambusai, Kecamatan Rambah, Kecamatan Rambah Samo, Kecamatan Kepenuhan, Kecamatan Tandun, Kecamatan Rokan IV Koto, dan Kecamatan Kunto Darussalam. Luas wilayah kerja Pembantu Bupati Kampar Wilayah I ini adalah 7.449,85 $\mathrm{km}^{2}$. Adanya pembagian wilayah mengakibatkan bertambahnya beban tugas dan volume kerja Pembantu Bupati Kampar Wilayah I dan Wilayah II dalam penyelenggaraan pemerintahan, pelaksanaan pembangunan, dan pembinaan kemasyarakatan.

Berdasarkan pertimbangan tersebut dan dengan memperhatikan aspirasi yang berkembang dalam masyarakat, maka pada tanggal 28 Juni 1999 lahirlah Keputusan Dewan Perwakilan Rakyat Daerah (DPRD) Kabupaten Kampar No. 05/KPTS/DPRD/1999 tentang Persetujuan Pemekaran Kabupaten dalam Wilayah Daerah Tingkat II Kampar. Keputusan DPRD Kabupaten Kampar tersebut kemudian ditindaklanjuti dengan Keputusan Dewan Perwakilan Rakyat Daerah (DPRD) Provinsi Riau No. 19/KPTS/Pimp/DPRD/1999 Tentang Rekomendasi Dukungan Terhadap Usul Pemekaran Wilayah Kabupaten Daerah Tingkat II di Provinsi Riau tanggal 24 Juni 1999. Usaha tersebut membuahkan hasil dengan keluarnya Undang-undang No. 53 Tahun 1999 Tentang Pembentukan Kabupaten Pelalawan, Kabupaten Rokan Hulu, Kabupaten Rokan Hilir, Kabupaten Siak, Kabupaten Karimun, Kabupaten Natuna, Kabupaten Kuantan Singingi, dan Kota Batam. Dalam undang-undang ini wilayah Kabupaten Kampar ditata menjadi tiga kabupaten, yakni Kabupaten Pelalawan, Kabupaten Rokan Hulu, dan Kabupaten Kampar (kabupaten induk).

Konflik tapal batas antara Kabupaten Rokan Hulu dan Kabupaten Kampar yang memperebutkan lima desa, yakni Desa Rimbo Jaya, Tanah Datar, Rimba Makmur, Muara Intan, dan Intan Jaya mulai muncul pada tahun 2005. Konflik ini muncul ke permukaan ketika Gubernur Riau yang pada masa itu dipimpin oleh Bapak Rusli Zainal mengeluarkan Peraturan Gubernur No. 30 Tahun 2005 Tentang Penegasan Status Wilayah Administratif Pemerintahan Desa
Intan Jaya, Tanah Datar, Muara Intan, Rimba Jaya, dan Rimba Makmur pada tanggal 19 Desember 2015. Dalam Pasal 2 ayat (1 dan 2) peraturan ini menyatakan bahwa ke lima desa tersebut masuk dalam wilayah Kabupaten Kampar. Keputusan tersebut bertentangan dengan Undang-undang No. 53 tahun 1999.

Keluarnya Peraturan Gubernur No. 30 Tahun 2005 bermula ketika terjadinya konflik elit di Desa Rimba Makmur. Pada tahun 2005 berlangsung pemilihan kepala desa di Rimba Makmur yang diikuti oleh 2 (dua) calon kepala desa, yakni Bapak M.S Haryono dan Bapak Drs. Sukio Budi (Wawancara dengan Tokoh Masyarakat Desa Rimba Makmur, Bapak Raymond Tobin Bekia).Pemilihan kepala desa tersebut dimenangkan oleh Bapak Drs. Sukio Budi. Bapak Haryono yang telah memegang jabatan kepala desa selama 2 periode (periode 19932000 dan periode 2000-2005) kalah dalam pemilihan kepala desa tahun 2005 ini. Bapak Haryono tidak menerima kekalahannya dalam Pemilihan Kepala Desa (pilkades) secara langsung. Bersama-sama dengan pendukungnya kemudian mengangkat isu tentang sejarah penitipan lima desa ke Kecamatan Kunto Darussalam. Isu ini disampaikan ke DPRD Kabupaten Kampar dan oleh DPRD disampaikan ke Provinsi Riau. Hingga keluarlah Peraturan Gubernur Riau yang menyatakan bahwa lima desa masuk dalam wilayah Kabupaten Kampar.

Dengan keluarnya Peraturan Gubernur tersebut, Pemerintah Kabupaten Rokan Hulu melakukan permohonan uji materi ke Mahkamah Agung (MA) pada tanggal 03 Maret 2006. Uji materi dilakukan pada pasal 14 ayat 10 Undang-undang No. 53 Tahun 1999 yang menyatakan bahwa batas wilayah secara pasti di lapangan ditetapkan oleh Menteri Dalam Negeri (Kemendagri). Permohonan uji materil yang disampaikan oleh Kabupaten Rokan Hulu tersebut dikabulkan oleh Mahkamah Agung. Mahkamah Agung menyatakan bahwa pasal 2 dan pasal 3 Peraturan Gubernur Riau No. 30 Tahun 2005 bertentangan dengan pasal 14 ayat 10 Undang-undang No. 53 Tahun 1999 dan tidak mempunyai kekuatan hukum. Jadi, yang berhak mengeluarkan penetapan batas wilayah antara Kabupaten Rokan Hulu dengan Kabupaten Kampar adalah Menteri Dalam Negeri. Dalam hal ini Gubernur 
Provinsi Riau hanya memberikan usulan berdasarkan hasil penelitian, pengukuran, dan pematokan di lapangan.

Berdasarkan hal tersebut, Mahkamah Agung menyatakan bahwa Peraturan Gubernur Riau No. 30 Tahun 2005 tidak sah dan tidak berlaku untuk umum. Mahkamah Agung juga meminta kepada termohon untuk segera mencabut Peraturan Gubernur Riau No. 30 Tahun 2005. Gubernur Riau kemudian mengeluarkan Peraturan Gubernur No. 24 Tahun 2006 yang mencabut Peraturan Gubernur No. 30 Tahun 2005. Dengan dicabutnya Peraturan Gubernur No. 30 Tahun 2005, maka status lima desa secara hukum masuk dalam Kecamatan Kunto Darussalam Kabupaten Rokan Hulu. Hal ini sesuai dengan pasal 4 Undang-undang No. 53 Tahun 1999. Seperti yang dijelaskan oleh Pakar Hukum Tata Negara Universitas Lancang Kuning Bagiyo Kadaryanto pada tanggal 08 September 2016 jam 15.00 Wib di Pekanbaru:

"Dalam Pasal 4 UU No. 53/1999 jelas bahwa lima desa masuk dalam Kecamatan Kunto Darussalam. Jika lima desa tidak masuk dalam Kecamatan Kunto Darussalam, maka dibuat kata "kecuali" seperti tiga desa yang tidak masuk dalam Kecamatan Tandun. Coba lihat pasal empat tersebut; Kecamatan Tandun, kecuali Desa Tandun, Desa Aliantan, dan Desa kabun."

Pencabutan Peraturan Gubernur Riau No. 30 Tahun 2005 semakin membuat kondisi di lima desa menjadi tidak kondusif. Konflik tapal batas terlihat tenang di luar, tetapi sebenarnya masih bergejolak di dalam. Hal ini ditunjukkan dengan munculnya dualisme kepemimpinan, yakni pemerintahan desa pro Kampar dan pemerintahan desa Pro Rokan Hulu dan terkotak-kotaknya masyarakat menjadi dua kubu, yakni kubu Pro Rokan Hulu dan Pro Kabupaten Kampar.

Konflik tapal batas antara Kabupaten Rokan Hulu dan Kabupaten Kampar ini muncul kembali ke permukaan pada tanggal 28 Juli 2008, yakni pada Pemilihan Gubernur Riau. Terjadi bentrokan antara Satuan Polisi Pamong Praja (Satpol PP) Kabupaten Kampar dan Kabupaten Rokan Hulu yang mengakibatkan sejumlah personil dari kedua belah pihak mengalami luka-luka. Bentrokan terjadi karena adanya surat Menteri Dalam Negeri No. 136/957/PUM tertanggal 19 Juni 2008 yang menyatakan lima desa dalam pelaksanaan Pilkada Riau pada September 2008 masuk dalam daerah pemilihan Kabupaten Kampar.

Pada tanggal 14 Agustus 2008 Menteri Dalam Negeri mengeluarkan surat No. $121.14 / 2500 / 08$ yang menyatakan bahwa Pilgubri tahun 2008 dilaksanakan oleh KPUD Kabupaten Rokan Hulu. Hal tersebut didasarkan pada fakta yuridis dan kenyataan pemerintahan yang didasari pada kesiapan infrastruktur dan data pemilih Pemerintah Kabupaten Rokan Hulu. Konflik kembali bereskalasi pada tanggal 28 Januari 2014, yakni terjadi bentrokan antara Satpol PP Kabupaten Kampar dengan Kabupaten Rokan Hulu. Bentrokan dipicu karena adanya kegiatan yang dilakukan oleh Pemerintah Kabupaten Kampar di lima desa.

Konflik tapal batas antara Kabupaten Rokan Hulu dengan Kabupaten Kampar yang memperebutkan lima desa (Desa Rimbo Jaya, Tanah Datar, Rimba Makmur, Muara Intan, dan Intan Jaya) senantiasa berubah setiap saat melalui berbagai tahapan aktivitas, intensitas, dan ketegangan serta kekerasan yang berbeda. Dengan memahami dinamika konflik tapal batas yang telah dijelaskan, maka akan dapat ditelusuri akar konflik yang sebenarnya.

Secara teoritis penyebab konflik tidak berupa faktor tunggal, melainkan terdiri atas beberapa faktor, seperti faktor struktural (yang berkaitan dengan kekuasaan, wewenang formal, kebijakan umum, peraturan perundang-undangan dan kebijakan lain), faktor kepentingan persoalan geografis dan faktor sejarah, faktor nilai, faktor sosial budaya, faktor ekonomi, faktor hubungan antar manusia, dan faktor perbedaan data (Afrizal, 2012; Firdaus, 2014; Kurniawati, 2012; Malik, Fauzi, Wijardjo, \& Royo, 2003). Berdasarkan hasil penelitian akar dari konflik tapal batas antara kabupaten Rokan Hulu dengan Kabupaten Kampar adalah konflik antara elitdesa yang kemudian meluas menjadi konflik antara Kabupaten Kampar dengan Kabupaten Rokan Hulu. Konflik kedua kabupaten sengaja dipelihara dengan tujuan tertentu. Hal ini diungkapkan oleh Tokoh Masyarakat Desa Rimba Makmur Raymond Tobin Bekia pada 
tanggal 31 Agustus 2016 jam 15.00 WIB di Rimba Makmur:

"Masyarakat di lima desa menjadi terkotak-kotak akibat konflik ini. Kalau lima desa masuk Kampar ya ditetapkan dan disosialisasikan. Kalau masuk Rohul juga begitu...Jangan lagi ada dua kepala desa seperti saat ini, masyarakat jadi bingung..Ini konflik sudah lama sekali, sejak tahun 2005.Tapi tak juga ada kejelasan hingga sekarang."

Konflik antara Kabupaten Kampar dengan Kabupaten Rokan Hulu bukanlah karena perebutan sumber daya alam yang ada di lima desa. Kedua kabupaten ini kaya akan sumberdaya alam, yakni perkebunan kelapa sawit dan penghasil minyak bumi. Hal tersebut dapat dilihat dari Peraturan Menteri Dalam Negeri No. 31 Tahun 2008 Tentang Penetapan Kabupaten Kampar dan Kabupaten Rokan Hulu Sebagai Daerah Penghasil Minyak Bumi Dari Sumur-Sumur Blok Langgak. Berdasarkan data dari Fitra Riau (2012) eksplorasi minyak di Kabupaten Kampar berada di wilayah Petapahan dan Tapung, sedangkan eksplorasi minyak Kabupaten Rokan Hulu terletak di wilayah Tandun. Dalam hal ini lima desa yang terletak di tapal batas antara Kabupaten Rokan Hulu dan Kabupaten Kampar bukanlah lokasi eksplorasi minyak bumi.

\section{JALUR LITIGASI: UPAYA PENYELESAIAN KONFLIK TAPAL BATAS KABUPATEN ROKAN HULU DAN KABUPATEN KAMPAR}

Jalur yang ditempuh dalam upaya penyelesaian konflik tapal batas antara Kabupaten Rokan Hulu dengan Kabupaten Kampar yang memperebutkan Desa Rimbo Jaya, Tanah Datar, Rimba Makmur, Muara Intan, dan Intan Jaya adalah jalur litigasi atau peradilan. Awal mula penyelesaian konflik tapal batas kedua kabupaten yakni dengan dikeluarkannya Surat Keputusan Menteri Dalam Negeri No. 135.6/824/SJ tanggal 02 Maret 2010. Terbitnya Surat Keputusan Menteri Dalam Negeri ini didasarkan pada; Pertama, surat Bupati Rokan Hulu No. 146/Pem/II/2006 tanggal 10 Februari 2006 perihal penegasan status wilayah administrasi pemerintahan lima desa dalam pelaksanaan pilkada Rokan Hulu tahun 2006 yang tembusannya ditujukan kepada Menteri Dalam Negeri; kedua, surat Sekretaris Daerah
Riau No. 100/PH/14.24 tanggal 30 Agustus 2007 perihal permasalahan lima desa yang tembusannya antara lain ditujukan kepada Menteri Dalam Negeri; ketiga, surat Gubernur Riau No. 140/PH/17.17 tanggal 17 Juni 2008 perihal status lima desa di Kabupaten Kampar dan Kabupaten Rokan Hulu yang ditujukan kepada Menteri Dalam Negeri; Keempat, surat Bupati Rokan Hulu No. 100/PEM/2008/693 tanggal 27 Juni 2008 perihal status lima desa di Kabupaten Rokan Hulu yang ditujukan kepada Menteri Dalam Negeri; kelima, surat Gubernur Riau No. 136/TPEM/82.11 tanggal 11 Mei 2009 perihal penyelesaian batas antara Kabupaten Kampar dengan Kabupaten Rokan Hulu yang ditujukan kepada Menteri Dalam Negeri; keenam, surat Bupati Kampar No. 100/PUM/112 tanggal 26 Januari 2010 perihal penegasan status lima desa yang disengketakan antara Kabupaten Kampar dengan Kabupaten Rokan Hulu yang ditujukan kepada Menteri Dalam Negeri.

Dalam keputusan ini Menteri Dalam Negeri menegaskan bahwa lima desa yang dipersengketakan antara kabupaten Kampar dengan Kabupaten Rokan Hulu berada dalam wilayah administrasi Kecamatan Kunto Darussalam, Kabupaten Rokan Hulu. Adapun dasar yang digunakan Menteri Dalam Negeri dalam penegasan status lima desa ini adalah: pertama, pasal 4 Undang-Undang No. 53 Tahun 1999 sebagaimana telah diubah dengan Undang-Undang No. 11 Tahun 2003 yang menetapkan bahwa Kabupaten Rokan Hulu berasal dari sebagian wilayah Kabupaten Kampar termasuk diantaranya seluruh wilayah Kecamatan Kunto Darussalam. Kedua, berdasarkan hasil analisis dokumen administrasi pemerintahan menunjukkan bahwa sebelum dan sesudah terbentuknya Kabupaten Rokan Hulu lima desa tersebut berada dalam pembinaan wilayah Kecamatan Kunto Darussalam. Ketiga, hasil survei di lapangan yang dilakukan oleh Tim Pusat menunjukkan secara de facto sampai saat ini, penyelenggaraan administrasi pemerintahan, pembangunan, dan sosial kemasyarakatan di lima tersebut berada dalam pembinaan wilayah Kecamatan Kunto Darussalam Kabupaten Rokan Hulu.

Pada tanggal 20 Mei 2010, Badan Permusyawaratan Desa (BPD) dari masyarakat lima desa melakukan gugatan ke 
Pengadilan Tata Usaha Negara (PTUN) terkait dengan surat Mendagri tersebut. Mereka meminta PTUN Jakarta untuk membatalkan Surat Keputusan Menteri Dalam Negeri No. 135.6/824/SJ. Alasan-alasan dalam gugatan masyarakat ke PTUN Jakarta adalah, pertama, keputusan Tata Usaha Negara yang digugat itu bertentangan dengan peraturan perundang-undangan yang berlaku; kedua, keputusan Tata Usaha Negara yang digugat itu bertentangan dengan asas-asas umum pemerintahan yang baik. Masyarakat lima desa yang melakukan gugatan melengkapi bukti tertulis berupa foto kopi surat-surat dan peta serta tiga orang saksi yang terdiri dari pensiunan kantor wilayah Badan Pertanahan Nasional Provinsi Riau, Kepala Bagian Bantuan Hukum dan HAM pada Biro Hukum Pemerintah Daerah Riau, dan staf Biro Tata Pemerintahan Sekda Provinsi Riau dan juga ketua dari Tim Penataan Penegasan Batas Daerah (PPBD) Provinsi Riau. Hasil keputusan dalam rapat permusyawaratan Majelis Hakim Pengadilan Tata Usaha Negara (PTUN) Jakarta tanggal 09 November 2010 menyatakan batalnya Surat Keputusan Menteri Dalam Negeri No. 135.6/824/SJ tanggal 2 Maret 2010 tentang Penegasan Status Wilayah ke 5 (lima) Desa. Pembatalan Surat keputusan Mendagri tersebut tertuang dalam Putusan Mahkamah Agung Republik Indonesia No. 65/G/2010/PTUN-JKT. Dengan dibatalkannya surat Menteri Dalam Negeri tersebut status lima desa masuk dalam wilayah Kabupaten Kampar.

Pada tanggal 23 November 2010 dilakukan permohonan Banding oleh Menteri Dalam Negeri dan Pemerintah Daerah Kabupaten Rokan Hulu ke Pengadilan Tata Usaha Negara. Dalam permohonan banding ini Majelis Hakim Pengadilan Tinggi Tata Usaha Negara Jakarta memutuskan, pertama, menerima permohonan banding dari Menteri Dalam Negeri dan Pemerintah Kabupaten Rokan Hulu. Kedua, membatalkan Putusan Pengadilan Tata Usaha Negara Jakarta No. 65/G/2010/PTUN.JKT tanggal 11 November 2010. Hal tersebut termuat dalam Surat Keputusan No. 17/B/2011/PT.TUN.JKT tanggal 02 Agustus 2011. Dengan dibatalkannya putusan Pengadilan Tata Usaha Negara No. 65/G/2010/PTUN.JKT, maka Surat Keputusan Menteri Dalam Negeri No. 135.6/824/SJ tanggal 2 Maret 2010 berlaku kembali. Status lima desa kembali pada wilayah Kabupaten Rokan Hulu.

Pada tanggal 22 Agustus 2011, Badan Permusyawaratan Desa (BPD) ke lima desa melakukan permohonan kasasi ke Mahkamah Agung. Dalam Putusan Mahkamah Agung No. 395K/TUN/2011 tanggal 10 September 2012 dinyatakan bahwa; pertama, mengabulkan gugatan dari BPD lima desa; Kedua, menyatakan batal Surat Keputusan Menteri Dalam Negeri No. 135.6/824/SJ tanggal 2 Maret 2010 tentang Penegasan Status Wilayah ke lima desa; Ketiga, mewajibkan Menteri Dalam Negeri mencabut Surat Keputusannya No. 135.6/824/SJ tersebut. Jadi, dengan adanya putusan Mahkamah Agung ini lima desa masuk dalam wilayah Kabupaten Kampar.

Dengan adanya putusan Mahkamah Agung No. 395K/TUN/2011, Menteri Dalam Negeri mencabut Surat keputusan Mendagri No. 135.6/824/SJ pada tanggal 31 Mei 2013. Pencabutan surat keputusan ini oleh Menteri Dalam Negeri semakin memperkuat bahwa lima desa masuk dalam wilayah Kabupaten Kampar. Hal ini kemudian diperkuat lagi dengan dikeluarkannya Peraturan Menteri Dalam Negeri No. 39 Tahun 2015 Tentang Kode dan Data Wilayah Administrasi Pemerintahan yang kemudian digantikan oleh Peraturan Menteri Dalam Negeri No. 56 Tahun 2015 Tentang Kode dan Data Wilayah Administrasi Pemerintahan pada tanggal 29 Juni 2015. Dalam Peraturan Menteri Dalam Negeri No. 56 Tahun 2015 tersebut lima desa masuk dalam kode wilayah Kabupaten Kampar. Dapat dilihat pada tabel 1.

Tabel 1

\section{Kode Wilayah Lima Desa Berdasarkan Permendagri No. 56 Tahun 2015}

\begin{tabular}{|c|l|l|}
\hline No & \multicolumn{1}{|c|}{ NamaDesa } & \multicolumn{1}{c|}{ Kode } \\
\hline 1 & MuaraIntan & 14.01 .12 .2005 \\
\hline 2 & Intan Jaya & 14.01 .12 .2006 \\
\hline 3 & Tanah Datar & 14.01 .12 .2007 \\
\hline 4 & Rimba Jaya & 14.01 .12 .2008 \\
\hline 5 & RimbaMakmur & 14.01 .12 .2009 \\
\hline
\end{tabular}

Sumber: Permendagri No. 56 Tahun 2015

Penyelesaian konflik lima desa telah dilakukan sejak tahun 2010 dengan keluarnya SK Mendagri No. 135.6/824/SJ yang menegaskan bahwa status lima desa berada dalam wilayah Kecamatan Kunto 
Darussalam Kabupaten Rokan Hulu. Surat Keputusan Mendagri ini kemudian digugat oleh Badan Permusyawaratan Desa (BPD) ke lima desa. Terdapat keganjilan dalam surat gugatan yang diajukan Badan Permusyawaratan Desa (BPD) lima desa tersebut. Dalam dalil gugatan poin 12 dinyatakan bahwa masyarakat lima desa menyatakan menolak wilayahnya ditetapkan masuk dalam wilayah Kabupaten Rokan Hulu. Dalil dalam gugatan tersebut bertolak belakang dengan kenyataan di lapangan. Seperti wawancara yang peneliti lakukan dengan Ibu Teti Suriati, PJS Kepala Desa Rimba Jaya Versi Kabupaten Kampar (2010sekarang), tanggal 01 Mei 2015:

"sebenarnya tidak ada masalah bagi masyarakat lima desa untuk masuk Kabupaten Kampar atau Kabupaten Rokan Hulu. Yang diinginkan oleh masyarakat dari dahulu adalah adanya kejelasan. Adanya keputusan yang berbeda-beda membuat masyarakat menjadi bingung."

Hal senada juga diungkapkan oleh Bapak Jono, masyarakat Desa Rimba Makmur, 01 Mei 2016:

"Bagi masyarakat ya terserah aja....masuk Rohul oke, masuk Kampar pun oke...yang penting ada kejelasan. Kalau tidak jelas seperti ini malah menimbulkan dampak negatif di masyarakat. Masyarakat menjadi terpecah-pecah. Para elit yang berkonflik, masyarakat yang menjadi korban..."

Terlihat jelas dalam gugatan BPD lima desa yang menyatakan masyarakat menolak masuk dalam Kabupaten Rokan Hulu bukanlah keinginan dari masyarakat lima desa seutuhnya. Hal tersebut merupakan keinginan dari segelintir elit desa yang telah ditunjuk sebagai PJS Kepala Desa Versi Kabupaten Kampar. Seperti wawancara dengan Daniel Hulu:

"Sejak terjadinya konflik di lima desa pada tahun 2005, masyarakat lima desa terpecah menjadi dua blok, yakni Blok Pro Kampar dan Blok Pro Rohul...."

Gugatan yang dilakukan BPD atas nama masyarakat di lima desa, akhirnya dikabulkan. Pengadilan Tinggi Tata Usaha Negara Jakarta kemudian membatalkan SK Mendagri No. 135.6/824/SJ tertanggal 2
Maret 2010. Menanggapi hal tersebut Menteri Dalam Negeri bersama dengan Pemerintah Kabupaten Rokan Hulu melakukan banding di Pengadilan Tinggi Tata Usaha Negara. Permohonan banding ini diterima dengan adanya pembatalan putusan PTUN No. 65/G/2010/PTUN JKT.

Dengan berlakunya kembali SK Mendagri No. 135.6/824/SJ tertanggal 2 Maret 2010 yang menyatakan lima desa masuk ke dalam wilayah Kabupaten Rokan Hulu belum menyelesaikan konflik antara Kabupaten Kampar dengan Kabupaten Rokan Hulu. Badan Permusyawaratan Desa (BPD) Pro Kampar melakukan kasasi ke Mahkamah Agung. Gugatan BPD ini dikabulkan oleh Mahkamah Agung dan dalam putusannya Mahkamah Agung meminta Mendagri untuk mencabut kembali SK Mendagri No. 135.6/824/SJ tertanggal 2 Maret 2010.

Putusan MA tersebut hanya membatalkan SK Mendagri dan tidak ada putusan yang menyatakan bahwa lima desa masuk dalam wilayah Kabupaten Kampar. Setelah keluarnya putusan MA ini status lima desa masih mengambang karena dalam Pasal 4 Undang-Undang 53 tahun 1999 masih dinyatakan bahwa Kabupaten Rokan Hulu memiliki tujuh kecamatan, salah satunya adalah Kecamatan Kunto Darussalam. Begitu pula dengan Permendagri No. 56 Tahun 2015 yang memasukkan lima desa ke dalam wilayah Kabupaten Kampar masih dapat digugat. Jadi, penyelesaian konflik lima desa dengan keluarnya Permendagri No. 56 Tahun 2015 tidak menyelesaikan akar permasalahan (Wawancara dengan Bapak Bagiyo Kadaryanto, Dosen Hukum Tata Negara Universitas Lancang Kuning, 08 September 2016).

\section{KESIMPULAN}

Penyelesaian konflik tapal batas antara Kabupaten Rokan Hulu dengan Kabupaten Kampar ditempuh melalui jalur litigasi/peradilan, yakni dengan keluarnya beberapa keputusan dari Kementrian Dalam Negeri, Pengadilan Tata Usaha Negara (PTUN) dan Mahkamah Agung (MA). Keputusan yang dikeluarkan oleh ketiga lembaga tersebut sangat membingungkan masyarakat karena hasil keputusan yang dikeluarkan berbeda-beda. Dalam SK Mendagri No. 135.6/824/SJ/2010 
menyatakan lima desa masuk dalam Kabupaten Rokan Hulu. Kemudian dalam SK PTUN No. 65/G/2010/PTUN-JKT menyatakan lima desa masuk dalam wilayah Kabupaten Kampar. Pada tahun 2011, PTUN melalui SK No. 17/B/2011/PTUN-JKT menyatakan bahwa lima desa masuk wilayah Kabupaten Rokan Hulu. Masih pada tahun yang sama keluar Keputusan Mahkamah Agung No. 395K/TUN/2011 yang membatalkan SK Mendagri No. 135.6/824/SJ/2010 dan menyatakan lima desa masuk dalam wilayah Kabupaten Kampar. Keputusan terakhir saat penelitian ini dilakukan adalah keluarnya Peraturan Menteri Dalam Negeri No. 39 tahun 2015 jo Permendagri No. 56 tahun 2015 Tentang kode dan data wilayah yang memasukkan lima desa kedalam wilayah Kabupaten Kampar.

Peraturan Menteri Dalam Negeri No. 56 Tahun 2015 yang menyatakan lima desa masuk dalam wilayah Kabupaten Kampar berpeluang untuk digugat kembali karena status lima desa dalam undang-undang No. 53 Tahun 1999 masuk dalam wilayah Kabupaten Rokan Hulu. Kebijakan Menteri Dalam Negeri tentang status lima desa tersebut perlu dibarengi dengan melakukan perubahan pada pasal 4 Undang-undang No. 53 Tahun 1999 Tentang Pembentukan Kabupaten Pelalawan, Kabupaten Rokan Hulu, Kabupaten Rokan Hilir, Kabupaten Siak, Kabupaten Karimun, Kabupaten Natuna, Kabupaten Kuantan Singingi, dan Kota Batam sebagaimana telah dirubah menjadi undangundang No. 11 Tahun 2003. Perubahan undang-undang tersebut kemudian disosialisasikan kepada Pemerintah Provinsi dan Pemerintah Kabupaten untuk selanjutnya disosialisasikan kepada masyarakat.

\section{DAFTAR PUSTAKA}

Afrizal, A. (2012). Kontestasi Ruang; Tinjauan Sosiologis Keadilan Ekologis. Jurnal Ilmu Sosial Mamangan, 1(1), 1-11.

BAPPENAS. (2008). Studi Evaluasi Dampak Pemekaran Daerah 2001-2007. Jakarta:
BAPPENAS.

Firdaus, F. (2014). Protes Korban Bencana; Studi Konflik Penanggulangan Bencana di Pasar Raya Padang. Jurnal Ilmu Sosial Mamangan, 1(2), 27-39.

Kurniawati, T. (2012). Konflik Dalam Penentuan Dana Bagi Hasil antara Pemerintah Pusat dan Pemerintah Propinsi Kalimantan Timur. Jurnal Ilmu Sosial Dan Ilmu Politik, 16, 16-25.

Malik, I., Fauzi, N., Wijardjo, B., \& Royo, A. (2003). Menyeimbangkan Kekuatan: Pilihan Strategi Menyelesaikan Konflik Atas Sumber Daya Alam. Jakarta: Yayasan Kemala.

Pamungkas, C. (2008). Politik Integrasi Dan Konflik Elit Lokal, Dalam Pemekaran: Studi Kasus Pembentukan Propinsi Irian Jaya Barat. In N. et. al. Retnaningsih (Ed.), Dinamika Politik Lokal di Indonesia: Penataan Daerah (Territorial Reform) dan Dinamikanya. Salatiga: PERCIK.

Ratnawati, T. (2009). Pemekaran Daerah: Politik Lokal dan Beberapa Isu Terseleksi. Jakarta: Pustaka Pelajar.

Ratnawati, T. (2010). Satu Dasa Warsa Pemekaran Daerah Era Reformasi: Kegagalan Otonomi Daerah? Jurnal Ilmu Politik, Edisi 21, 122-235.

Roth, D. (2007). Gubernur Banyak, Provinsi Tak Ada: Berebut Provinsi di Daerah Luwu-Tana Toraja di Sulawesi Selatan. (G. Van Klinken, Ed.). Jakarta: KITLV. Tahara, T. (2008). Pemekaran Wilayah dan Kontestasi Elit POlitik Lokal. (W. P. Retnaningsih, Ning., Samiana, I Made., Pulungan, Halomoan., Setyanto, Ed.). Salatiga: Persemaian Cinta Kemanusiaan (PERCIK).

Tirtosudarmo, R. (2008). Pemekaran Sebagai Arena Perebutan dan Pembagian Kekuasaan: Kritik Terhadap Dominasi "Public Administration School." (W. P. Retnaningsih, Ning., Samiana, I Made., Pulungan, Halomoan., Setyanto, Ed.). Salatiga: Persemaian Cinta Kemanusiaan (PERCIK). 